Милош М. Ковачевић*

Филолошки факултет Београд

Филолошко-уметнички факултет Крагујевац

https://doi.org/10.18485/ai_petrovic_goran.2020.ch7

821.163.41.09 Петровић Г.

811.163.41'38

\title{
О СТРУКТУРИ И СТИЛИСТИЦИ РЕЧЕНИЦЕ У СИТНИЧАРНИЦИ „КОД СРЕЋНЕ РУКЕ” ГОРАНА ПЕТРОВИЋА
}

Циљ рада је да се издвоје и опишу структурне и стилистичке доминанте реченице и (микро)дискурса у роману Ситиничарница „Ко срећне руке” Горана Петровића. А двије су темељне структурно-стилистичке доминанте реченице и/или (микро)текста у роману Ситиничарница „Коg срећне руке", а то су: 1) амплификација, и 2) еквивалентност. У раду се даје структурно-стилистичка анализа реченичних и микродискурсних конструкција како са амӣлибикацијом

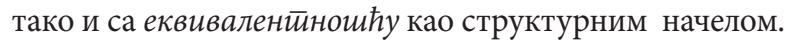

Кључне ријечи: Горан Петровић, реченица, микротекст, структура, стилистика, амплификација, еквивалентност

У синтаксичкој и стилистичкој литератури тешко је наћи ослонац за испитивање структурно-стилистичких особености реченице једнога писца. Посебно још ако се ради о писцу за кога познати критичари кажу да је „данас најбољи стилист српске прозе. Језик се у свему што га добрим чини отргао од свих обичних правила - па је то

* mkovacevic31@gmail.com 
чак збунило и оног стручњака који се стално бави језичким недоумицама - и постао сила сам по себи” (Јерков 2005:20), односно да су његове књиге „прави језички мајдани, празници речи, а похвала његовим књигама у ствари је похвала језику”, јер он спада међу „неколико прозних писаца који предњаче не у употреби, него у ірађењу језика, и баш је у том погледу, зарад своје микростилске, лексичке, синтаксичке па, ако хоћете, и археолошке слојевитости, репрезентативан језик прича и романа Горана Петровића" (Пантић 2005:10-11).

Дате се изјаве, међутим, могу прихватити само као аксиолошке, јер није понуђен ниједан критеријум на основу кога су изречене. То не значи да нису тачне, али будући да не почивају ни на једном егзактном критеријуму, то не значи ни да су тачне.

Ако се за некога каже да је најбољи „стилист српске прозе”, тешко да се таква констатација може потврдити или порећи уколико се егзактно не испита структура и стилистика његове реченице, што онда, по законитости међуодноса реченице и текста, подразумијева и структуру микро и макротекста или микро или макродискурса ${ }^{1}$ као надреченичног јединства, будући да се из перспективе текста или дискурса реченица (увијек у вриједности исказа) дефинише као дио текста или дискурса који и сам може бити текст или дискурс. А колико ми је познато, таквих синтаксичко-стилистичких истраживања не само текстова Горана Петровића него ни других српских па и словенских писаца - није билоㅇ. Ријетке монографије о стилистици реченица за предмет углавном издвајају: 1)

1 Термине „(микро)текст” и „(микро)дискурс” у овоме раду употребљавамо као синониме.

2 Интересантно је, и готово невјероватно, да у докторској дисертацији насловљеној Поеиика ӣрозе Горана Петировића (Шаренац 2016) нема ни једне једине реченице, а камоли поглавља, о Петровићевом језику. 
варијантност одређеног реченичног модела, првенствено се интересујући за његове синонимне или боље рећи блискозначне варијације, засноване прије свега на конкурентности различитих везника или пак варијација унутар реда ријечи или компонената (Формановска 1978), или 2) улогу одређених морфосинтаксичких јединица у обликовању структурног или комуникативног типа (монопредикатске) реченице (Јовановић 2013).

Кад се прочита роман Сийничарнииа „Коg срећне руке”, код свих читалаца остаје неподијељен утисак о његовом стилском савршентсву. Само што доминанте тог савршенства не чине засигурно ни (не)супституентност везника, ни варијантност реда компонената, ни улога одређених морфосинтаксичких јединица. Баш као што се тим критеријумима не може освијетлити ни стилско савршенство реченице Ива Андрића (в. Живковић 1982). Али поређење структуре и стилистике Андрићеве и Петровићеве реченице (овдје само оне из Ситиничарнице) показало би неупоредиво више разлика него сличности. Двије су, као то показује Д. Живковић (1982), структурно-стилистичке доминанте Андрићеве реченице: 1) специфична интонациона структура („интонационо таласање”), условљено употребом апозитива и предикатских апозитива, најчешће у функцији атрибутско-прилошке одредбе, и 2) „антитетичка, контрастна структура Андрићеве мисли и реченице, која се гради свим могућим контрастним фигурама (антитеза, парадокс, антиметабола, игра речима) и која просто плави његово казивање” (Живковић 1982: 264-267).

Реченица Горана Петровића, која стилски не заостаје за реченицом Ива Андрића, заснива се на потпуно друкчијим структурно-стилистичким доминантама, а то су: 1) амплификација, и 2) еквивалентност.

Амплификација је структурно начело реченице у роману Ситиничарниияа „Коg срећне руке”. Амплифи- 
кација подразумијева стилско нагомилавање „више разних појединости да што точније прикаже свој предмет” (Шкреб 1986:257). „Амплификација је заправо фигуративна категорија која уједињује бројне фигуре конструкције и мисли (анафору, епитет, емфазу, енумерацију, градацију, хиперболу, парафразу, перифразу, поредбу, синонимију, таутологију и сл.). Исказ се њоме орнаментализира, а мисао нијансира, обогаћује и оплемењује” (Багић 2012: 30-31), што за резултат има „непоновљивост појединачног виђења” (Багић 2012:31). Тако схваћена амплификација подударна је синатроизму (или синатрезму), који подразумијева гомилање „различитих појединости ... у функцији стварања емоционалне обојености” (Катнић-Бакаршић 1996:46), односно „низање ријечи, израза или суреченица ради што подробнијег приказа или што исцрпнијег описа" (Багић 2012:291).

\section{Амйлификаиија као сӣрукииурно начело Петировићеве речениче}

Познато је да је „у књижевности амплификација особито подесна за дескрипцијско развијање теме, минуциозно приказивање, различите облике детаљизирања и наглашавања приказиваног лика, ситуације, призора или мисли”, што омогућава „непоновљивост појединачног виђења" (Багић 2012: 31). Та тврдња као да је проистекла из анализе реченица Горана Петровића у Сийничарниии „Коg срећне руке”. Петровићеве су амплификативне реченичне структуре и на плану стилематичности реченице, тј. на плану њеног структурног устројства, и на плану стилогености ${ }^{3}$ реченице, што ће рећи на плану њене умјетничке (естетске) вриједности - доведене до

3 О типовима и међуодносу стилогености и стилематичности в. у Ковачевић (2015: 323-324) и (2018:1-21). 
савршенства. Једноставно речено, оне су тако синтаксички и стилистички обликоване да остављају утисак „непоновљивости”. Али, не само „непоновљивости појединачног виђења" као њиховог стилогеног, умјетничког ефекта, него можда још више непоновљивости стилематичног реченичног устројства, тј. начина синтаксичке творбе. У Петровићевим је реченицама амплификативно начело реализовано у толиком броју различитих структурних варијаната, да их је у једноме немонографском раду немогуће све и поменути, а камоли описати.

Стилематичну структуру Петровићевих амплификативних реченица могуће је представити с обзиром на различите критеријуме: а) критеријум (не)хомофункционалности нагомиланих јединица, б) критеријум типа нагомиланих језичких јединица, в) критеријум типа нагомилавања језичких јединица, г) критеријум начина творбе текста или дискурса. Иако се у самом дјелу могу пронаћи примјери у којима је заступљен само један од наведених критеријума, неупоредиво су чешћи случајеви у којима се истовремено преплићу најмање два, а покаткад и сва четири критеријума. Зато ћемо овдје навести само неколико примјера амплификативних Петровићевих реченичних структура из Ситиничарнице „Коg срећне руке” с најмање двама од наведених, али и са додатним критеријумима усложњавања њихове стилематичне структуре.

Амплификацијски низови јединица код Петровића, као и иначе, најчешће су хомофукиионални. То значи да нагомилане јединице редуплицирају исту синтаксичку функцију или позицију: субјекатску, прилошкоодредбену, или пак атрибутску, као нпр.:

(1) Павиљон је заправо био једна једина просторија натрпана запаром и сваковрсним стварима. Улазећи, младић уочи десетине великих и малих кутија, појединачно одло- 
жених или наслаганих до паса, па и преко висине човека, баштенске алатке, поцепану мрежу за чишћење рибњака и окрпљену мрежу за хватање лептира, шумарски чекић за обележавање дебала, низ саксија са тек избилим расадом, нераспремљен кревет и хладан термофор, полудубоке ципеле са металним ојачањима, калемарске маказе, подеран сламнати шешир, пиргава јаја у тегли са некаквом течношћу, у углу комаде разбијеног женског попрсја од порфира, мало даље допола слепљену зделу осликану хеленистичким мотивима, свежањ геометарских штапова, клупче канапа, метлицу, и још једну сиркову метлицу, металну четку, зарђале узенгије, на некаквом сталку за цвеће пар бакрених новчића и сребрну копчу, ниже сталка шпаклу, подебели хербаријум са извирелим петељкама листова, по поду разврстано камење, уломке керамике и шарног стакла, као и цедуљице са некаквим бројевима, а на великом столу, од простих дасака, бочице туша, размерник, шестар, угломер, лупу, пинцету и план читавог поседа, различито шрафираних површи, са уцртаним крстићима и котама, положајем објеката и вињетом у десном заглављу, где је калиграфски писало: „Идеална реконструкција настанка подручја, 1 : 10.000, од проф. Д. Тиосављевића." (85-86) ${ }^{4}$.

Оно што као инваријанта повезује све наведене амплификцијске јединице јесте њихова објекатска синтаксичка функција. Све амплификативне јединице, а њих је, како видимо, на десетине, јесу хомофункционалне и падежно хомоформне: у функцији су акузативног правог објеката уз глагол уочи $\bar{u} u^{5}$. Али нису све синтаксички истоврсне,

4 Број у загради означава са које је сранице издања романа, чији се библиографски подаци дају у Извору на крају рада ексцерпиран дати примјер.

5 Будући да цијели амплификацијској структури реченице припада сав њен дио иза предиката, а и да синтаксичка функција амплификативних јединица зависи од глагола у предикату, при навођењу примјера глагол у предикату истакли смо и истицаћемо курзивом. 
jep су изражене или супстантивном синтаксемом или супстантивном синтагмом у функцији беспредложног акузативног правог објекта. Тако је амплификацијски низ остварен као хомофункционално низање именичких синтаксема и супстантивних сантагми различите сложености. И не само да су функционално него су и „предоџбено” обједињене, јер представљају слику „сваковрсних ствари” омеђену агенсовим погледом („уочавањем”). Створена је визуелна слика „начичкана” предметима које граматички обједињује хомофункционалност, а прагматички „видокруг омеђен уочавањем”.

Готово цијела амплификативна реченица асиндетски је структурисана ${ }^{6}:$ нагомилане јединице одвојене су запетама, с тим да је између запета покаткад уметнута везничка независна координирана синтагма, и то најчешће у случајевима када координиране именице чине неку врсту цјелине (као нпр. „уломке керамике и шарног стакла” и сл.), или се пак покаткад атрибутском амплификацијом усложњава и нека од супстантивних лексема у амплификацијском објекатском низу (као нпр.: „... пинцету и план читавог поседа, различито шрафираних површи, са уцртаним крстићима и котама, положајем објеката и вињетом у десном заглављу” и сл.). У питању je, дакле, амплификација која не само да није моноврсна према типу укључених синтаксичких јединица (него најмање двоврсна: синтаксемска и синтагматска), него није ни монофункционална (него је најмање довофункционална: објекатска и атрибутска).

6 Амплификацијске структуре су најчешће, али не и искључиво асиндетске. Петровић твори, истина рјеђе, и полисиндетске амплификацијске реченичне структуре, као нпр.: Домаћица је била затечена, пртљаг није садржао ништа друго осим мноштва примерака књига, ни један једини одевни или лични предмет, ни употребљавану кошуљу, ни марамицу, ни чешаљ, ни распарено дугме за манжетну, ни фотографију, ни четкицу или прашак за зубе, заиста ништа друго. (144). 
Нису, међутим, Петровићеве амплификативне реченичне структуре варијантне само у погледу типа у њих укључених синтаксичких јединица и типа синтаксичке функције коју дијеле. Петровић се често у творби амплификацијских хомофункционалних структура користи и поступком парцелације ${ }^{7}$ и то тако што асиндетско запетама обиљежено низање амплификацијских јединица прекида тачком. И то тачком на мјесту запете, као нпр.:

(1a) Не већа од скучене, просторија опште намене сagpжала је само расходовани архивски роло-ормар, више пута обијане браве, дубећи чивилук, две климаве столице, радни сто и саксију са сневољеном стабљиком божијег дрвцета. Омањи радни сто, искрзаних ивица, испошћене политуре, једва довољан за шест предратних томова Речника Матице српске, поратно издање Правописа и хрпу овонедељних, свеже натрукованих новинских текстова. (7).

У питању је, као што се види, амплификација све самих синтагматских супстантивних јединица у позицији правог објекта уз глагол саgржавати. Али та амплификација не сеже само до наредне тачке, зато што та тачка не представља реченичну границу, тј. крај претходне и почетак наредне реченице. Запетама обиљежено низање прекинуто је послије шесте супстантивне амплификативне објекатске синтагме тачком. Та тачка не значи, међутим, крај амплификативног низа, него је употријебљена умјесто запета из стилистичко-експресивних разлога: да унутар амплификативног низа посебно истакне његову посљедњу компоненту - „омањи радни сто”. На тој амплификативној компоненти, међутим, није комуникативни фокус, нити је она

7 Парцелација је интерјунктурно „интонационо и позиционо осамостаљење неког реченичног конституента: синтаксеме, синтагме или клаузе" (Ковачевић 2015:342-343). 
разлог употребе парцелације. Разлог парцелацији јесте посљедња од трију за ту компоненту (за „омањи радни сто”) синтаксички везаних а амплификативно изражених атрибутских синтагми, а то је адјективна синтагма, такође амплификацијски структурисана, с придјевом „довољан” као централним чланом, унутар које комуникативни фокус представља „шест предратних томова Речника Матице српске” и „поратно издање Правописа”. Управо због тих двију јединица, иако су оне синтаксички тек посредно укључене у амплификацијски низ, али су битне за тематику цијелог романа, писац је и прибјегао парцелацији као синтаксичко-стилистичком поступку, којим је структурно-семантички осложнио амплификативно устројство реченице.

Парцелација није једини начин синтаксичко-стилистичког усложњавања реченичне амплификације. Горан Петровић на различите начине стилистички усложњава већ парацелацијом усложњене амплификативне реченичне структуре. Један од начина јесте интерференција парцелације и силейсе роgа и броја као стилске фигуре (Ковачевић 2015:220), какав је случај у сљедећем, неусамљеном, примјеру:

(16) Уоколо се налазио потребан багаж. И више од тога. Шкриња, три замашна ковчега, шест кофера и туце облих кутија за шешире, свака са цедуљицом или утиснутим монограмом власнице. (26).

Све амплификативне јединице обједињене су субјекатском функцијом уз предикат налазийи се. Амплификативни низ субјекатских јединица (синтаксема и синтагми) осложњен је двоструком парцелацијом, одмах након навођења првог у низу субјеката („багаж”). И само с тим првим субјектом предикат конгруира у роду и броју

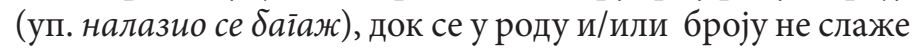


ни са једним од парцелисаних субјеката (уп.: ${ }^{\star}$ налазио

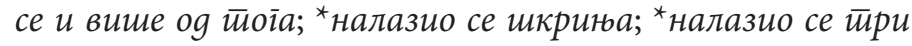
замашна ковчеїа, итд.). Тако је парцелација као синтаксичко-стилистички поступак фигуративно осложњена силепсом рода и броја, чиме је амплификација двоструко стилистички маркирана: постала је и семантички сложенија и поетски валентнија.

Петровић неријетко ствара и привид парцелације, остварујући амплификацију низањем номиналних исказа, неподводљивих под парцелацију, као нпр.:

(1в) У понедељак навече, 20. новембра, пошто се вратила из Народне библиотеке, затекла је госпођу како усплахи-

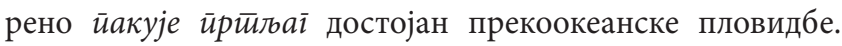
Тоалета за дневне и ноћне прилике, топлија одећа, обућа, спаваћице, ноћне капе, марамице, четке за косу и обрве, маникир прибор, стакла са миришљавом водицом, албуми са фотографијама, јабуке, ако их жеђ снађе... (64).

Наведени примјер изгледа подударан претходним двама (1a/16) у погледу синтаксичког устројства амплификационог низа синтаксичких јединица. Изгледа као да је у питању низ с парцелацијом амплификативних синтаксичких јединица након прве, након именице „пртљаг” у функцији правог објеката уз глагол йаковайи. Међутим, ниједна од наредних синтаксема или супстантивних синтагми не дијели с наведеним објектом („пртљаг”) ни форму ни функцију - није у акузативу нити има објекатску функцију. Зато и није могућа замјена тачке запетом (уп. ${ }^{\star}$ Пакује пртљаг достојан прекоокеанске пловидбе, $\overline{\text { } о а л е и ̆ а . . . ., ~}$

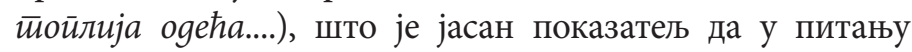
није парцелисана амплификатива реченица. У питању је амплификација номиналних, беспредикатских исказа, којима синтаксички мјесто не отвара предикату $\bar{u} а к о в а \bar{u} u$, јер они нису синтаксички колокабилни с тим предикатом 
па у односу на њ и не врше ниједну синтаксичку функцију. Амплификација, дакле, није дата у форми граматичке реченице, него у форми комуникативне реченице или исказа, насталог елипсом (уп. Ту су били йоалети $а, \bar{u} о \overline{и л а ~}$ ogeћa, обућа, сйаваћице... итд.). А елипса и парцелација синтаксички се битно разликују ${ }^{8}$, јер је елиптична структура посебан исказ или комуникативна реченица, док је парцелисана структура само дио претходног исказа или реченице. Но, без обзира на синтаксичку самосталност амплификативних исказа у односу на предикат претходне реченице, те су јединице семантички подређене датом предикату, односно предикатско-објекатској синтагми „пакује пртљаг”. Наиме, свим наведеним асиндетским амплификативним исказима означавају се дијелови пртљага, тако да су они с именицом „пртљаг” у односу меронимије: ${ }^{9}$ сви су они мероними именице „пртљаг”, која је њихов холоним (уп.: тоалета је дио пртљага; одећа је дио пртљага; обућа је дио пртљага, и сл.). А то онда значи да се улога амплификације и не исцрпљује у оквиру реченице и/или исказа, него у оквиру текста или дискурса.

8 „Као основу разликовања елипсе од парцелације можемо узети чињеницу да суглавна реченица и парцелат заправо реализација једне реченичне конструкције, док је свака елиптична реченица засебна у односу на реченицу која је окружује. Осим, тога, парцелисани искази се лако укључују у главну реченицу која им обично претходи, док елиптичне реченице то не могу. Уколико једноставним укидањем тачке одвојени парцелати могу лако да се придруже претходној реченици, онда се ради о парцелацији, а не о елипси. Овој принцип можемо да узмемо као правило разликовања парцелације од елипсе" (Вујевић 2017:162).

9 Меронимија подразумијава однос дијела и цјелине, с тим да се појам који означава цјелину назива холоним, а појам који означава дио назива се мероним. „Меронимијска формула гласи: А је дио Б-а, на примјер рука је део иеела, волан је део ауйомобила итд., а „тест за препознавање меронимије сачињава реченица: Х(олоним) има М(ероним): иеело има ілаву, ауйомобил има волан итд." (Драгићевић 2007:293). 
Основна функција амплификативних структура Горана Петровића у роману Сийничарница „Коg срећне руке" јесте текстуална или дискурсна. Амплификација је не само дио (микро)текста него и начин његовог структурисања. У (микро)тексту је амплификација често дио структуре guстирибуције као стилске фигуре ${ }^{10}$. И то или као катафорски или као анафорски структурисане дистрибуције. У амплификацијски катафорски структурисаним дистрибуцијама најприје се наводи неки општи појам који се конкретизује, идентификује, „опримјерује” амплификацијским јединицама што иза њега слиједе, као нпр.:

(1г) Има људи чији је укупан изглед потчињен само оgређеном gелу иеела, спојеним веђама, истакнутим јагодицама, љубопитљивим уснама, спуштеним раменима, несразмерним боковима или равним стопалима. Наталија Димитријевић се несумњиво убрајала у такве. (33-34).

у анафорски структурисаним амплификацијским дистрибуцијама (микро)текст се развија тако што се најприје амплификацијски нижу конкретнији појмови чије се значење "сажима" неком општијом јединицом с анафоричком граматичко-текстуалном функцијом, као нпр.:

(1д) Столица са рукохватима, радни сто од ораховине, наочари танког оквира, челична пера, озбиљна држаља, кристална мастионица, овални упијач, нож за хартију од слонове кости, лампа са зеленим стаклом, пречетворене „Београдске новине”, „Нови покрет”, „Дневни лист” и

10 Дистрибуција као стилска фигура подразумијева језичку структуру у којој се најприје наводи „неки општи појам који се у даљем тексту навођењем његових саставних дијелова 'индивидуализује"' (Ковачевић 2015:314), или пак структуру у којој се најприје наводе саставни дијелови неког општег, „обједињавајућег” појма који иза њих слиједи. 
„Трговачки гласник”, пресавијена „Политика” и вероватно „Штампа”, мада је била одложена тако да јој се заглавље не види, као и цела спратна кућа на Великом Врачару, потоњој Звездари, сав йај савршени йореgак уосталом - припадао је адвокату Славољубу Т. Величковићу, дечаковом очуху. (97).

У двама наведеним примјерима амплификације имају улогу или десцедентног (1г) или асцедентног (1д) развијања текста, зависно од тога да ли се амплификацијским низом конкретизује неко општије значење, тј. да ли се у развијању текста иде од општег (апстрактнијег) ка низу конкретн(иј)их појмова (1г), или се пак амплификацијски низ конкретних појмова своди на неки општији појам, тј. да ли се у развијању текста иде од конкретних ка општ(иј)ем (апстрактнијем) појму (1д).

Да у Петровићевом роману Ситиничарница „Коg срећне руке” амплификацијске структуре имају улогу текстуалног развијања, најбољу потврду дају (микро) текстови у којима амплификацијски низ чине глаголи у предикатима, или тачније речено: асиндетске предикатске структуре. А низање предикатских садржаја за резултат увијек има (микро)текст, без обзира да ли је он синтакстички оформљен као низ јукстапонираних клауза или пак као низ самосталних реченица (исказа). За потврду наводимо само два примјера, у којима глаголе као носиоце амплификацијских предикатских структура курзивно истичемо:

(15) На ужагреним плотнама шпорета на дрва, из читавог

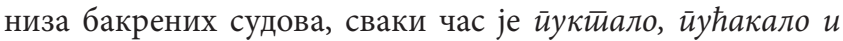
йућйурућкало, брболило, іріольло и жвріолило, иврчало, крчкало и цееитиило...(89);

Тог поподнева, јорговани су уступили место ружама,

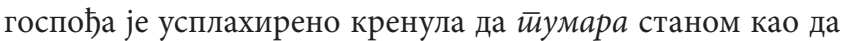
тиражи нешто посебно. Обилазила је собу по собу, иелла се на лестве у библиотеци, саїиғала се да привири испод кре- 
вета и канабета, йоgизала је тепихе и столњаке, ойварала ормаре, извлачила фиоке, изврииала џепове и кутијице са накитом, писмима и прибором за шивење, зурила је у углове, уздисала и кршила прсте. (58).

Глаголске амплификације најексплицитније показују да је амплификација не само реченична него и текстуална структурна доминанта овог Петровићевог романа. И не само то, него предикатске амплификације на својеврстан начин негирају у књижевнотеоријској литератури изношено мишљење (в. нпр. Алексић 2013:283; Турањанин 2014: 80) да се амплификацијске конструкције могу подвести под каталог као поступак навођења тематски различитих „спискова или побројавања” најчешће у епској поезији, одакле је пренесен и у друге „врсте и жанрове” (Речник 1992:342). Каталошким, наиме, никада нису сматране глаголске, односно предикатске амплификације, а оне су недвосмислено амплификативни микротекстови или дискурси. Нису сматране каталозима, али у реторици јесу прагматографијом као врстом хипотипозе. Хийойuйоза је заправо општа стилска фигура описа, која се, с обзиром на предмет описа, дијели у више подврста, и то најчешће на: а) еøикиију - опис визуелних карактеристика човјека; б) йайойejy - опис афективних (психолошких) човјекових карактеристика, в) ејкон - опис карактеристика неког физичког предмета, г) йраїмайоірафију - опис неког човјековог поступка (нпр. радње или акције),

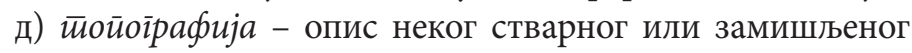
мјеста, ђ) ейойејy - опис обичаја, е) gијайийозу - опис пејзажа или неког амбијента (о типовима хипотипоза в. Ковачевић 1998:75-78). Детаљна, за предмет нашег рада небитна, тематска анализа Петровићевих амплификацијских структура без сумње би потврдила ако не све а оно већину подврста хипотипозе, будући да је амплификација свима њима темељно структурно начело. 


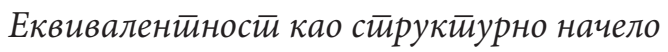
Пеировићеве реченице

Уз амплификацију, а неријетко и у интерференцији

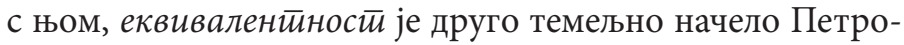
вићеве реченице у Сиитниарници „Коg срећне руке”. Кад се у вези с књижевношћу помене еквивалентност, то одмах асоцира на Јакобсонову поетску функцију језика. Јер, „поетска функција пројектује принцип еквивалентности из осе селекције у осу комбинације" (Јакобсон 1996:296). Тако схваћена, поетска функција еквивалентност уздиже до конститутивног начела пјесме, јер тежи изједначавању различитих типова конститутивних елемената у дијеловима или у цјелини пјесме. Принцип еквивалентности, према томе, Јакобсон не приписује као најбитнију особину језику књижевности у цјелини, него само језику поезије.

А управо таква јакобсоновска еквивалентност као изједначеност или (потпуно) подударање форми језичких јединица унутар реченичних и (микро)текстуалних структура - представља и структурно начело Петровићеве реченице и (микро)текста у Ситиничарници „Коg срећне руке”. Еквивалентност као једна од суштаствених особина Петровићевог прозног израза експлицитно је или имплицитно уочена код књижевних истраживача Петровићеве поетике. Тако је, без шире елаборације и егземплификације, С. Илић констатовала да је у Сийничарници Петровићев „језик у функцији онеобичавања и лиризације прозног дискурса: понављају се поједини изрази у дискурсу и на тај начин се постиже ритмичност, као основно својство лирике" (Илић 2005: 144). Слична ја и тврдња А. Јеркова да је „већ је у самом језгру његовог [Петровићевог] приповедања нешто песничко као такво" (Јерков 2005:20), јер у Петровићевој реченици „песничко као такво" једино може подразумијевати еквивалент- 
ност као темељни принцип поетског (пјесничког) језика. И заиста еквивалентност као „правилно” понављање 11 јесте, уз амплификацију, основни принцип структурисања како Петровићевих реченица тако и Петровићевих (микро)дискурса у Ситиничарници „Коg срећне руке”. Али, начело еквивалентности у Петровићевој прози, како ћемо видјети, никако се не може поистовијетити са Јакобсоновим начелом еквивалентности у поезији.

У творби реченице и (микро)дискурса Петровић остварује многобројне и структурно разнородне типове еквивалентности. Поменућемо само неке: а) анафорска еквивалентност (понавља се иста језичка јединица на почетку више клауза или реченица), б) полиптотонска еквивалентност (понавља се иста језичка јединица или њен дио у различитим морфолошким формама унутар сваке од клауза или реченица), в) прстенаста еквивалентност (понавља се иста или дјелимично модификована јединица у почетној и завршној клаузи или реченици), г) реитерацијска „пилонска" еквивалентност (понавља се најмање двапут структурно „чворишна”, „пилонска” компонента преко које се даље усложњава структура сложене реченице или микротекста), и д) амплификацијска еквивалентност (сложена реченица или микротекст развија се понављањем амплификацијских конектора ${ }^{12}$ унутар микродискурса).

Навешћемо за сваки од наведених типова по један примјер, у коме курзивно истичемо структурно еквивалентне јединице:

11 Еквивалентност као понављање подударних граматичких и/ или синтаксичких јединица није синониман, него је шири појам од синтаксичког паралелизма као стилске фигуре. Но, „у много случајева синтаксички паралелизам не само да се као стилска фигура преплиће с различитим врстама еквивалентности него се он и реализује кроз различите типове еквивалентности" (Брезински 1984:81).

12 О амплификативним конекторима в. Силић (1984: 119). 
(2a) Одлажући оловку и растворену књигу на груди, не разодевајући се, он само привуче ћебе и стаде да тоне у снове. Сағьао је да је заспао у оном истом врту и да на образу осећа нечији дах. Санао је да се буди, да се придиже и очи у очи сусреће - предивног, белог једнорога. Сањао је како то митско створење привија главу уз његово раме. А онда је сағьо, страшне ли море - да се пробудио и да ништа више не може да сања. (93);

(26) Много, много пута касније, Анастас Браница се спуштао низ ону исйу стрмину, мимо оних истиих оштрих трава и вијугавих камених подзида, сенки маслина и дивљих нарова, на оно истио, уско жало, у подножју рта, крај оне истие, непрегледне воде - погнуто трагао за било чиме што ће потврдити да је као дете ту боравио. (104);

(2в) Крет̄ао се кроз тај свеколики метеж астраханских калпака са белим перима, изгланцаних кокарди, еполета, еполетушки и ширита, плавих мундира, гарансцрвених чакшира, крљуштаних подбрадника сјајних шлемова, аша, парадних коњских покроваца, урешених билава, високих чизама у узенгијама, пешадијских, артиљеријских и нових униформи припадника одскора формираног аеропланског и балонског одељења - кретиао се и један младић необично зажагрених очију. (125);

(2г) Истина, подсетила се Јелена, простори неких књига су изгледали као окамењени. [...] Било је књиїа које су садржале само прошлост, тако давну прошлост да су облици постојали само захваљујући привиђењима. Кюиіа којима се проносио људски ромор, музика и смех, да би пришавши затекао - столетни одјек. Или кюиїа које су походили само посвећени, настојећи да из преосталог обнове изглед какве грађевине или испод заборава, тежег од свега најтежег, извуку вредећу помисао. И постојала је стварност која је личила на такве къиіе, само се, за разлику од њих, није могла склопити, одложити. (58); 
(2д) Две жене, јеgна млада, gруїа у одмаклим годинама, прихватиле су се истоветних, растворених књига. Прва стегнута до грча, са мучнином ниже грудне кости, ознојених дланова. Друї нетремице, горљивих очију иза увеличавајућих стакала наочара. (64).

Наведени примјери су парадигматични, они репрезентују тип еквивалентности синтаксема или синтагми унутар сложених реченица или микротекстова. Сваки од наведених типова еквивалентности реализује се код Патровића у низу структурно-стилистичких варијација, с тим да се неријетко комбинује са асиндетски структурисаном амплификацијом (што експлицитно потврђују и примјери под 26 и 2в). Осим тога, код Петровића је прије чест неголи риједак случај да се два или више типова синтаксичке еквивалентности реализују унутар истог (микро)дискурса, као нпр.:

(2ђ) Склопивши око подне књигу о хеленистичкој архитектури, заденувши кончић за сећање, јер час везења са мадам Дидије сам што није почео, Натали је на сваком оg својих иритежа затекла тог, како јој се представио, Анастаса Браницу. Овgе - како седи и нешто јој прича. Онgе - како је пажљиво слуша. Тамо - како за њу бере гранчицу мирте. Онамо - како јој пружа руку да пређе преко потока.

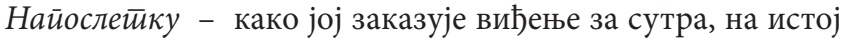
страни, у истом одељку. Сваки, баш сваки оg иртенса садржао је његов бледи лик или штркљасту фигуру и Натали Увил, од те близине - букну у лицу. (160);

Тако је повучено живео Анастас Браница по свом деветогодишњем избивању из земље. У посете није одлазио. Нити је кога примао. Уосталом, йешко да је кога и знао. Још йеже да је њега неко присније познавао. Живео је проводећи време у бескрајном читању книіа на француском или оних на српском језику, кюиіа које је неутаживо набављао и по своме повратку. Затворен у бившој 
очуховој радној соби. Некаgа не излазећи данима. Некаgа читајући ноћу, у замену за измакле снове. Некаgа свечано одевен, као за славље или пријем, са шеширом, марамицом у заџепку. рукавицама и гамашнама. Некаgа босоног, само у раздрљеном кућном хаљетку, испод којег до мушкости није носио ама баш ништа. Некаgа толико дуго и далеко одсутан, да се враћао упалих образа и знојав. Некаgа се појављујући свеж и бодар, као да се међу редове упустио пре фртаљ часа, а не од када је устао, на очи прогледао. (147-148).

У првоме примјеру комбинована је прстенаста и специфична анафорична еквивалентност: прстенаста је везана за редупликацију синтагме, а анафоричка за низање замјеничких прилога, с тим да је та анафоричка еквивалентност комбинована и са интонационом еквивалентношћу, јер је иза свакога од прилога употребом црте маркирана пауза. Друга је реченица још више испреплетена типовима еквивалентности: двапут је остварена „пилонска” реитерацијска еквивалентност (с глаголом живетии и именицом књиі̄a), потом су двије реченице повезане анафорско-градацијском еквивалент-

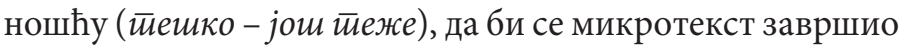
са шестоструком анафором лексеме некаgа употријебљеном на почетку сваке од структурно сложених парцелисаних јединица.

Иако је, уз амплификацију, еквивалентност у Сuйничарници темељно начело структурисања реченице и (микро)дискурса, иако се по томе начелу Петровићева проза готово подудара са поезијом - ипак је тешко сложити се са констатацијом да сама еквивалентност као симетрично понављање синтаксичких јединица подразумијева „лиризацију прозног дискурса”, будући да се тиме „Постиже ритмичност, као основно својство лирике” (С. Илић), односно да је еквивалентност кад је она „језгро 
приповедања” иманентно „песничко као такво” у реченици Горана Петровића (А. Јерков).

Најбољи показатељ да су дате оцјене, еуфемистички речено, олако и неаргументовано изречене јесу

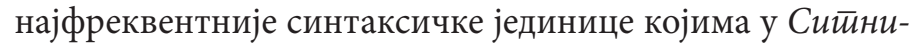
чарници Горан Петровић твори еквивалентност и/или синтаксички паралелизам. А то су іляа̄олски ӣрилози, и то и глаголски прилог прошли и глаголски прилог садашњи. А глаголски прилози (или вербиди) међу најрепрезентативнијим су типовима кондензатора реченичног значења, односно „нереченичних језичких средстава (тј. средстава без предикације у финитном глаголском облику) у функцији саопштавања реченичног садржаја" (Радовановић 1990:13).

Горан Петровић врло често употребљава и глаголски прилог садашњи и глаголски прилог прошли као језичке јединице којим остварује синтаксички паралелизам по правилу унутар монопредикатске реченице, тј. реченице с једним предикатом у личном глаголском облику. Да би конструкција с глаголским прилогом добила статус конструкције синтаксичког паралелизма, глаголски прилог сам или као надређени члан синтагме мора бити у монопредикатској реченици најмање двапут реализован.

Ако се за критеријум типова еквивалентности узме позиција глаголских прилога у односу на предикат, онда се еквивалентне структуре с глаголским прилозима у Сийничарници реализују и/или као а) антепозицијски низ (синтагме с глаголским прилозима долазе испред предиката), и/или као б) постопозицијски низ (синтаксички паралелне синтагме долазе послије предиката), и/ или као в) „прстенасти” или антепозицијско-постпозицијски низ (синтаксички паралелизам творе синтагме с глаголским прилозима смјештеним и испред и иза предиката). Сваки од наведених трију линеарно реализованих паралелизама остварених глаголским прилозима, 
чешће као центром глаголске синтагме него самим, у Ситиничарници се потврђује немалим бројем примјера. Овдје ћемо навести само по неколика примјера за паралелизме с оба глаголска прилога, сама или комбинована, у свим трима позиционим типовима синтаксичких паралелизама, с тим да ћемо при навођењу реченичних примјера глаголске прилоге као носиоце еквивалентних синтаксичких конструкција истицати курзивом, а предикат подвлачењем:

(3а) Покуцавии на врата радне собе, ирриінувщи оно здраво уво, друго затииснувии малићем, да не чује тишину, ушавши на Анастасов позив, затекла је младог човека како блажено гледи у ону исту књигу и жудно пали цигарету на цигарету. (161); Изашавши из зграде, оямакавши неколико корака навише, младић се окрену, а да ни сам није знао зашто. (246); С муком се йровукавши између попречених аутомобила, иррешавщи на другу страну улице Милована Миловановића, ӣeюући се ка гарсоњери, Адам Лозанић је све јасније чуо суседово укуцавање лајсни за рамове. (251); Склойивщи око подне књигу о хеленистичкој архитектури, заgенувши кончић за сећање, јер час везења са мадам Дидије сам што није почео, Натали је на сваком од својих цртежа затекла тог, како јој се представио, Анастаса Браницу. (160); Не исйушйајући књигу, стиежући је до белила на зглобовима прстију, више увређен речима него ударцем, он је истрчао из очухове собе. (102) итд.

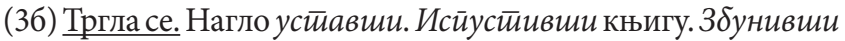
$c e$, не знајући да ли да прво поправи хаљину или да се обује. (114); Ситном кишом запретене среде, с јесени 1906, Анастас Браница, тада тек дванаестогодишњак, седео је за очуховим радним столом, чийајући књигу, тихо звижgућући неку дечију корачницу и млатиарајући ногама. (97); У недељу се Адам Лозанић неколико пута предомишљао, ӣрекиgајућu рад на роману у више наврата, сирремајући се да изађе из стана, па се опет враћајући књизи повезаној у сафијан. (301); 
Слав. Величковић је долазио у правилним размацима, ирровоgећи сате и сате у разговорима са удовицом, пажљиво саyчестивујући у причама о њеном претходном браку, устиајући и нуgећи јој своју беспрекорно испеглану марамицу, уједно веома мало іоворећи о себи. (109); Послове је обично уі̄oварао без писаних трагова, закључујући их само срдачним руковањем, лаковерно остиявљајући предујам, често се и не иреgстиављьјући, још ређе образлажући разлоге загонетних наруџбина. (186); А онда је данима отварао, затварао и опет отварао огромни путни ковчег, постављен нацигованим па проштепаним меким мирисом једног другог света, ваgећu из његове сеновите дубине - књигу за књигом, ойpecajyћu

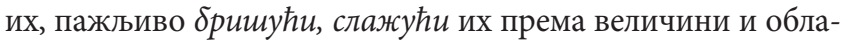
стима, на веће или мање купе. (144); - Глупи глупане! - оо은 je cебе ноћу, врйолећи се у нагужваној постељи, устиајући и залуд лежући, некада све до јутра. (123) итд.

(3в) Неколико година касније, склайајући коначну верзију рукописа, сам Браница је извршио многа скраћивања, ириклағајући се смиренијим стиловима, без превише украса. (189); Не окусивши ништа читава три дана, не осећајући потребу за водом, храном, сном, не осећајући ни она друга телесна морања, отупео од празнине, пежао је на софи, ослушкујући како у њему не одјекује ни живот, оgлазећи само до оног жала, пенасте међе песка и мора, у пустоловној књизи за децу, са утиснутом представом васељенског дрвета, што је као дванаестогодишњак читао. (215); Избивии најзад на узано жало, нагло је успорио, йовлачећи ноге кроз

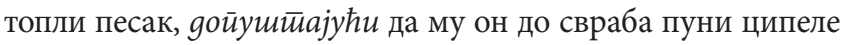
и чарапе спале до чукљева. (99); Таманећи их уместо штићенице, мадам Дидије се страшно угојила од тих слаткиша, облапорно их їуйајућu, уз колутање очима, забављајући се потом прављењем кугле од омота. (179-180) итд.

Код Горана Петровића у Сийничарници су, како се види, врло обичне и фреквентне синтаксички еквивалентне реченичне конструкције са глаголским прило- 
зима. Оба глаголска прилога нису, међутим, подједнако честа у сва три позициона типа синтаксички еквивалентних синтагми. Чешће се с глаголским прилогом прошлим остварују антепозицијски синтаксички паралелизми него с глаголским прилогом садашњим. Насупрот томе, неупоредиво су бројнији примјери постпозицијског синтаксичког паралелизма с глаголским прилогом садашњим него с глаголским прилогом прошлим. У „прстенастом” паралелизму најчешће учествују синтагме с учешћем обају прилога: и глаголског прилога прошлог и глаголског прилога садашњег. А таква дистрибуција није случајна: глаголски прилог прошли твори се од свршених глагола и њим се обиљежава радња која се дешава прије радње предиката, па та временска карактеристика налази свој пандан у антепозицијској реализацији синтагми глаголског прилога прошлог у односу на предикат. Глаголски прилог садашњи твори се, међутим, од имперфективних глагола, тако да примарно означава истовременост радње са радњом предиката. Будући да је радња глаголског прилога комуникативно секундарна у односу на радњу предиката, логично је да је постпозиција њена примарна позиција у односу на предикат.

Глаголски прилози су, већ је напоменуто, кондензатори реченичног значења par excellence, а употреби кондензатора уопште „нарочито погодују специјални функционални стилови језичкога стандарда, нпр. новинарски, правни, политички, научни, административни и сл., док се у просеку двоструко мањи број примера с реченичним кондензаторима бележи у језику књижевних дела. Ово се тумачи у првом реду екстралингвистичким моментима, а то су интелектуализованост, уопштеност и апстрактност тематике оног домена језичке употребе којем дати функционални стил служи као референцијални инструмент" (Радовановић 1990: 15). Глаголски прилози као кондензатори реченичног значења су, дакле, показатељ инте- 
лектуализације, а не лиризације језичког израза. Данас је општеприхваћено становиште Пражана да је интелектуализација насупротна актуализацији или дезаутоматизацији језичких средстава. „Интелектуализација представља апстрактан начин изношења свеколике сложености мисли и стога најизразитије долази у Н[аучном] Ф[ункционалном] С[тилу] ('научном језику') (Тошовић 2002:32), док је актуелизација или дезаутоматизација језичких средстава суштаствена особина поетског језика (Тезе 1986: 162, 164).

Све то јасно показује да принцип еквивалентности, мимо поезије, нужно не значи „лиричност реченице”, нити пак исти тип ритмичности поетских и прозних јединица. Еквивалентност јесте конструктивно начело Петровићеве реченице баш као што је и конструктивно начело поетског израза уопште, али то не значи да је стилогени ефекат реализоване еквивелентности исти у ова два типа књижевног израза. Томе је више него добар показатељ чињеница да су у поезији глаголски прилози, посебно глаголски прилог прошли, тако ријетки у употреби (да просто није ни могуће замислити пјесму засићену глаголским прилогом прошлим!), а у Петровићевој прози тако чести и функционални. Једино је неспорно да еквивалентност остварена у оквиру реченице заиста тој реченици прибавља посебан ритам, али опет неподударан ритму и синтаксичко-интонационој структури што их еквивалентност задаје стиху или строфи. Ако суштину ритма чини симетрија реченичних или дијелова стиха, онда се ритам Петровићеве реченице може поредити с поетским ритмом. Прозни ритам, међутим, никада није комбинован с метром, док поетски ритам готово увијек представља метричко-ритмичко јединство. Уз то треба имати у виду и чињеницу да у поезији метричко-ритмичко јединство увијек има примат над синтаксичко-интонационим и семантичким јединством, чему су најбоља потврда стихови с опкора- 
чењем (Ружић 2008:160), док је у прози обрнуто: синтаксичко-интонациони и семантички критеријуми имају примат над ритмичким ${ }^{13}$.

Као што ни амплификација код Петровића није структурно начело само реченице него и (микро)текста, тако је и са еквивалентношћу: и она је структурно начело не само реченице него и (микро)текста. Показаћемо то само на једном примјеру микротекста који представља форму синтаксички потпуног управног говора, компонованог од ауторске дидаскалије или конферансе као ауторског говора и цитираног говора лика као туђег говора:

(3г) Враћајући се у кујну и йристиављајући воду, ређајући тацне и шољице, непрестано је гунђала због силне кафе што је неки од гостију ишту тако касно навече:

- Црно на црно, па где то иде?!

Или се льуйећи због сијасет боца ризлинга и сифона соде, што је посетиоцима ранораниоцима, онима са нападним уметничким машнама, пелеринама и шеширима великог обода, вазда орним за бесплатно пиће, строго упарено, још јутром морала да изнесе:

- Бело на бело, то нема нигде?!

Али, надасве неїоgyjyћи зато што Анастас неумерено пуши и тако слабо једе:

- Испашће наопако, пуј три пута преко рамена! Како је онамо, у тим својим писанијама све присутнији, овде само што не нестане! (193).

Овај врло карактеристичан микротекст туђег управног говора ${ }^{14}$ чине три кратке реплике управног говора

13 Тако нпр. у прозним Петровићевим реченицама еквивалентни искази с глаголским прилозима нужно изазивају паузу типа антикаденце, док антикаденцу нужно не подразумијева крај стиха, чему су најбољи показатељ управо стихови са опкорачењем.

14 О типовима туђег говора и њиховим карактеристикама в. Ковачевић (2012:13-38). 
издвојеног унутар текста цртом као ортографским знаком „цитатности”. Испред сваке од реплика реализован је ауторски говор у форми ауторских дидаскалија или конферанси ${ }^{15}$. У три ауторске дидаскалије синтаксичка еквивалентност остварује се употребом глагола у форми глаголског прилога садашњег: у првој дидаскалији остварује се низ од три глаголска прилога садашња, док је у другој и трећој дидаскалији употријебљен по један глаголски прилог садашњи. Тако су све три дидаскалије обједињене структурном еквивалентношћу, с тим да је та еквивалентност морфолошка: заснована на реитерацији глаголског прилога садашњег. Али то није једини тип еквивалентности између трију наведених ауторских дидаскалија. С том структурном морфолошко-синтаксичком еквивалентности интерферира семантичка еквивалентност остварена између предиката прве дидаскалије израженог перфектом (іунђала је) и глагола у форми глаголских прилога друге (љуйећи се) и треће дидаскалије (неіоgуjућu). Та три глагола, истина други (љуйећи се) тек преко прегнанције као стилске фигуре (Ковачевић 2015:261-263) припадају групи експресивних глагола типа verba dicendi, употријебљених у функцији више помишљеног (солилоквијумског) но изреченог управног говора. Тако глаголски прилози у другој и трећој дидаскалији успостављају двоструку еквивалентност с глаголима прве дидаскалије: синтаксичку еквивалентност са глаголима у форми глаголског прилога садашњег, а семантичку еквивалентност са перфекатском

15 Роман Сийничарница „Ко срећне руке” вјероватно је јединствен у погледу обима и структурисања ауторских дидаскалија или конферанси уз управни говор. Ауторске дидаскалије су врло развијене, имају врло сложену структуру, а изражене су врло често вишеструкосложеним реченицама или чак микродискурсима. А кад су изражене монопредикатском реченицом, најчешће су те реченице структурно усложњене или амплификацијама или синтаксички еквивалентним јединицама. 
формом глагола у предикату. Та два типа нису, међутим, једини типови еквивалентности које карактерише овај микродискурс туђег говора. Еквивалентан однос између друге и треће дидаскалије остварује се и употребом независних везника (или и али) у анафорској, иницијалној позицији дидаскалије. Ти везници показатељи су синтаксичке несамосталности датих дидаскалија. Ти везници упућују на то да су садржаји изражени глаголским прилозима у координираној синтаксичкој вези (и то дисјунктивној и адверзативној) са садржајима глаголских прилога у првој дидаскалији. Уз то, дати везници показују да су наведене дидаскалије синтаксички парцелисане структуре прве дидаскалије, и то у литератури досад незабиљежене дистантне парцелације (јер су од парцелисане структуре одвојене репликом туђег говора). А и три наведене реплике помишљеног управног говора такође структурно еквивалентне, јер им је подударна интонационо-синтаксичка структура, на што упућују њихови завршни интерпункцијски знаци: све три реплике дијеле компоненту узвичности, с тим да се у првој и другој реплици она усложњава компонентом упитности. Друкчије речено, прву и другу реплику чине упитно-узвични искази, док је трећа, због своје финитивне (затварачке) микротекстуалне улоге, ослобођена компоненте упитности и сведена само на узвични исказ.

Анализа датог микродискурса управног говора показала је да се у њему, с обзиром на јединство ауторске дидаскалије и туђег управног говора, остварује читава мрежа еквивалентности: морфолошка, синтаксичка, семантичка, конекторска, парцелацијска и интонациона еквивалентност. Зато дати примјер на најбољи начин потврђује тврдњу да је еквивалентност, и то најчешће усложњена, уз амплификацију структурно начело реченице и/или микротекста Горана Петровића у Сийничарнищи „Ко срећне руке”. 


\section{Зактучак}

Двије су темељне структурно-стилистичке доминанте реченице и/или (микро)текста у роману Ситиничарница „Ко срећне руке”, а то су: 1) амплификација, и 2) еквивалентност.

Петровићеве амплификативне реченичне структуре и на плану стилематичности реченице, тј. на плану њеног структурног устројства, и на плану стилогености реченице, тј. на плану њене умјетничке (естетске) вриједности - доведене су до савршенства. Оне су тако синтаксички и стилистички обликоване да остављају утисак „непоновљивости”. Али, не само „непоновљивости појединачног виђења" као њиховог стилогеног, умјетничког ефекта, него можда још више непоновљивости стилематичног реченичног устројства, тј. начина синтаксичке творбе. У Петровићевим је реченицама амплификативно начело реализовано у великом броју различитих структурних варијаната, с тим да се неријетко унутар исте реченице или (микро)текста реализују различити типови амплификација.

Са амплификацијом, а неријетко и у интерференцији с њом, еквивалентност као правилно понављање неке синтаксичке јединице јесте основни принцип структурисања како Петровићевих реченица тако и Петровићевих (микро)дискурса у Сийничарници „Ко срећнеруке”. Анализа је показала да се начело еквивалентности у Петровићевој прози никако не може нити смије поистовијетити са Јакобсоновим начелом еквивалентности у поезији.

У творби реченице и (микро)дискурса Петровић остварује многобројне и структурно разнородне типове еквивалентности, а најчешће: а) анафорска еквивалентност, б) полиптотонска еквивалентност, в) прстенаста еквивалентност, г) реитерацијска „пилонска” еквивалентност, и д) амплификацијска еквивалентност, с тим 
да се тиме типови еквивалентности у реченици или (микро)тексту Сийничарниие не исцрпљују.

Анализа структурно-стилистичких особина Петровићеве реченице и/или микротекста показала је да језик Горана Петровића припада Вук-Андрићевој линији књижевног језика у функцији језика књижевности. Језик Петровићев, попут Андрићевог, представља узор књижевног (стандардног) српског језика као језика књижевности, изузме ли се само једна, с обзиром на наведену оцјену, готово необјашњива парадигматичка ненормативна црта: неграматичка негација у адјективним синтагмама с процесуалним придјевом као надређеним чланом, типа никаgа намакнуйе (завесе) ${ }^{16}$.

16 Те неграматичне адјективне синтагме, чију ћемо граматички и/или нормативно исправну форму давати у загради са стрелицом, честе су у роману Ситиничарница „Коg срећне руке”, и то чак чешће у ауторском неголи у језику ликова, чему су потврда сљедећи ексцерпирани примјери: ...застаде крај знамените Митићеве рупе, највећег замишљеног Робног магазина на Балкану, својевремено никаgа йоgиīнуйо $\bar{\imath}[\rightarrow$ нейоgиінуйой] и потом никаgа срушеноі [ $\rightarrow$ несрушеної], а онда настави поред продаваца кестења...(16); ...када је застала испред врата госпође Наталије, ничим изgвојених [ $\rightarrow$ неизgвојених] од осталих улазних врата станова на петом спрату зграде у Палмотићевој улици (29); Можда је то било због онолике, грунуле светлости, крупно нецаних, па још

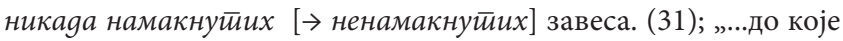
мере човек може да обневиди у погледу сопствених, а ничим $\bar{u} о g р ж а н и x$ [ $\rightarrow$ нейоgржаних] хтења." (76); И тако је госпођица Наталија Димитријевићева остала да живи између две љубави. Оне своје, никаgа изречене [ $\rightarrow$ неизречене]. (200); Захтевнијих и спроведених исправки било је више него ранијих дана, од новог распореда намештаја у салону, преко ничим ойравgаноі $[\rightarrow$ неойравgаної] подизања једног унутрашњег зида, чиме је трпезарија беспотребно преграђена на два скучена дела (303) и сл. О овом типу системски неграматичких и ненормативних негацијских синтагми и разлозима њихове несистемности и ненормативности в. опширно у Ковачевић (2004: 249-252). 


\section{ИЗВОРИ}

Горан Петровић, Ситиничарица „Коg срећне руке”, десето издање, Београд: Народна књига- Алфа, 2001 (у СІР-у 2000, на поткорици 2001).

\section{ЛИТЕРАТУРА}

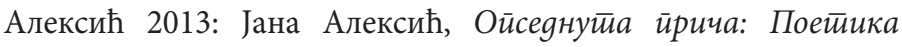
романа Горана Петировића, Београд: Службени гласник.

Багић 2012: Krešimir Bagić, Rječnik stilskih figura, Zagreb: Školska knjiga.

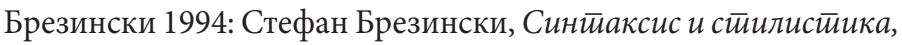

София: Университетско издателство „Св. Климент Охридски".

Вујевић 2017: Вера Вујевић, Елийса у срӣском и енїлеском, Београд: Јасен.

Драгићевић 2007: Рајна Драгићевић, Лексиколоіија срӣскоі̄ језика, Београд: Завод за уџбенике.

Живковић 1982: Драгиша Живковић, „Неколико стилских одлика прозе Иве Андрића (поводом Проклетее авлије, изд. Матице српске, Нови Сад, 1955)", Евройски оквири срйске кюижевностии III, Београд: Просвета, 258-276.

Илић 2005: Слађана Илић, Нешт̄о се ийак gоїоgило. Оїлеgи о савременој срӣској ӣрози сезоне 2000-2004, Зрењанин: Агора.

Јакобсон 1966: Roman Jakobson, Lingvistika i poetika, Beograd: Nolit, 1966.

Јерков 2005: Александар Јерков, „Име уметничке истине”, у: Савремена срӣска ирроза: Зборник gваgесей ирввих књижевних сусрети $a, \delta p .17$, уредник Верољуб Вукашиновић, Трстеник: Народна библиотека „Јефимија”, Културно просветна заједница Трстеник, 19-23.

Јовановић 2013: Јелена Јовановић, Линівистиички и стиилистиччки асиектии ӥроучаваюа реченице, Београд: Јасен.

Катнић-Бакаршић 1996: Marina Katnić-Bakaršić, Gradacija: Od figure do jezičke kategorije, Sarajevo: Međunardoni centar za mir. 
Ковачевић 2004: Милош Ковачевић, Оїлеgи о синйаксичкој неїацији, Српско Сарајево: Завод за уџбенике и наставна средства.

Ковачевић 2012: Милош Ковачевић, „О граматичко-стилистичком терминосистему туђег говора”, Срйски језик, XVII, Београд, 13-38.

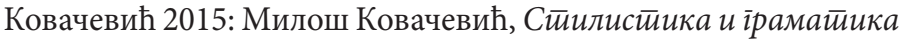
стиилских фиіура, IV битно допуњено издање, Београд: Јасен.

Ковачевић 2018: Милош Ковачевић, „Стилистика у настави српскога језика”, Кюижевносӣ и језик, LXV/1-2, Београд, 2018, 1-21.

Пантић 2005: Михаило Пантић, „Језик, машта и равнотежа”, у: Савремена срйска йроза: Зборник gваяесей йрвих кюижевних сусрети $a, \delta p .17$, уредник Верољуб Вукашиновић, Трстеник: Народна библиотека „Јефимија”, Културно просветна заједница Трстеник, 9-11.

Радовановић 1990: Milorad Radovanović, „O 'kondenzaciji rečenice' kao jezičkom postupku”, u: Spisi iz sintakse $i$ semantike, Sremski Karlovci: Izdavačka knjižarnica Zorana Stojanovića, Novi Sad: Dobra vest, 13-27.

Речник 1992: Речник књижевних йермина, уредник Драгиша Живковић, Београд: Нолит.

Ружић 2008: Žarko Ružić, Enciklopedijski rečnik versifikacije, Sremski Karlovci - Novi Sad: Izdavačka knjižarnica Zorana Stojanovića.

Силић 1984: Josip Silić, Od rečenice do teksta: Teoretsko-metodološke pretpostavke nadrečeničnog jedinstva, Zagreb: Sveučilišna naklada Liber.

Tезе 1986: R. Jakobson, N. Trubecki, V. Matezijus, B. Havranek, P. Bogatirjov, N. Durnovo, J. Mukaržovski i P. Savicki, „Teze Praškog lingvističkog kružoka”, u: Jan Mukaržovski, Struktura pesničkog jezika, Beograd: Zavod za udžbenike i nastavna sredstva, 153-182.

Тошовић 2002: Бранко Тошовић, Функционални сииилови, Београд: Београдска књига.

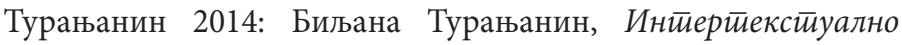




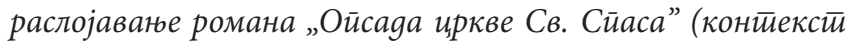
„Библије” и среgновјековне книжевностии у настиави), необјављена докторска дисертација одбрањена на Филозофском факултету у Новом Саду 16. 9. 2014.

$<$ http://nardus.mpn.gov.rs/bitstream/handle/123456789/9047/

Disertacija15436.pdf? sequence $=1$ \&isAllowed $=y>$

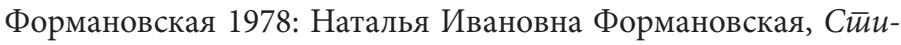
лисииика сложноіо ирреgложения, Москва: Издательство „Русский язык”.

Шаренац 2016: Слободанка Шаренац, Поейика йрозе Горана Пейровића, необјављена докторска дисертација, одбрањена на Филолошком факултету у Београду 2016.

<http://nardus.mpn.gov.rs/bitstream/handle/123456789/6103/ Disertacija4055.pdf? sequence $=1>$

Шкреб 1986: Zdenko Škreb, „Mikrostrukture stila i književne forme”, u: Zdenko Škreb, Ante Stamać, Uvod u Književnost: Teorija, metodologija, IV, poboljšano izdanje, Zagreb: Globus, 233-282.

Miloš Kovačević

\section{ON STRUCTURE AND STYLISTICS OF THE SENTENCES IN THE NOVEL A SMALL SHOP "AT THE HAPPY HAND“ BY GORAN PETROVIĆ}

\section{Summary}

The paper singles out and describes structural and stylistic dominants of sentence and (micro) discourse in the novel A Small Shop "At the Happy Hand" by Goran Petrović. The analysis proves that the two basic structural and stylistic dominants of sentences and / or (micro) discourse in the novel A Small Shop "At the Happy Hand" are 1) amplification; 2) equivalence. 
Petrovićs amplificational sentential structures considering both the level of the stylematic quality of the sentences or their structural pattern and of their stylogic quality value are perfected to the utmost. So superbly are they shaped that their syntax and style leave the impression of the unprecedented originality. It is not only the "uniqueness of the individual insight" that contributes most to the overall stylogenic, artistic effect but even more the originality of their stylematic pattern or the way their syntactic formation are structured. In Petrović's sentences the amplification rule is effected in the great number of different structural variants whereas it often happens that within the same statement or (micro) text there are different types of amplification.

Together with amplification and often with the interference goes the equivalence as the regular repetition of some syntactical unit which makes the second basic structural principle of both Petrovićs sentences and his (micro) discourses in the novel. The analysis proved that the principle of equivalence in Petrovićs prose must not be equalled with Jakobson's principle of eqiuvalence in poetry.

Key Words: Goran Petrović, sentence, microtext, structure, stylistics, amplification, eqivalence. 